\title{
LAND TENURE SYSTEM AND AGRICULTURAL PRODUCTIVITY IN A SELECTED AREA OF BANGLADESH
}

\author{
Mahmuda Nasrin and M. Taj Uddin \\ Department of Agricultural Economics, Bangladesh Agricultural University, \\ Mymensingh-2202, Bangladesh
}

\begin{abstract}
The relative efficiency of farming under tenancy systems in Bangladesh was measured in this study. Thirty cash tenants and 30 share tenants were randomly selected for data collection through field survey method from Narayanpur and Bhabokhali villages under Sadar upazila of Mymensingh district. The functional analysis of the study was based on Boro rice. The land tenancy situation in rural Bangladesh was explored in this study with a reasonable high incidence of owners who cultivate their own land in comparison to owner-cum-tenants and tenants. A number of tenurial arrangements including sharing agreements were also revealed in the study villages. Share tenant farmers earned significantly lower net return (Tk. 19,252.18) than the cash tenant farmers (Tk. 22,815.89) from Boro rice production. However, Boro rice production was profitable from the viewpoint of both tenant operators. Finally, the study tested and confirmed that all the explanatory variables (key production inputs) included in the CobbDouglas revenue type production function model were important for explaining the variations in gross returns under both tenancy arrangements.
\end{abstract}

Key Words: Relative efficiency, Tenurial arrangements, Sharing agreements, Cash tenants

\section{INTRODUCTION}

Land is a limited resource and its distribution as well as tenure structures are viewed as key issues in nation's developmental strategy. Bangladesh has a long history of inequitable access to land. About fifty two percent of the rural population, which accounts for almost 75 percent of the country's population, is landless or holds less than 0.5 acre of land. One percent of landowners own more than 7.5 acres. Ten percent of landowners own between 2.5 and 7.5 acres. The remaining 89 percent of landowners own less than 2.5 acres. Thirty nine percent have less than 0.5 acre. However, such inequity exists despite a series of land reforms in the 1950s and 1960s that included tenancy reforms, imposed ceilings on landholdings and provided for the distribution of public land to the landless (GOB, 2008; Uddin and Haque, 2009).

\footnotetext{
* The paper has been derived from the first author's Master's thesis submitted to the Department of Agricultural Economics, Bangladesh Agricultural University, Mymensingh-2202, Bangladesh
} 
The term tenure means the bundle of rights an individual, household or community may have with respect to land or water or other resources for that matter. With land tenure, the meaning is restricted to rights related to land, their origin and their operation (Bruce, 1993). According to FAO (1993), land tenure is the relationship, whether legally or customarily defined, among people, as individuals or groups, with respect to land. In simple terms, land tenure systems determine who can use what resources for how long and under what conditions.

Land tenure systems affect agricultural productivity by influencing the efficient use of inputs and adoption of modern technology. The development of agriculture sector is very much urgent for poverty reduction and sustainable development of the country. Despite steady progress towards industrialization, agriculture remains the most important sector in Bangladesh. About 20 percent of Gross Domestic Product (GDP) of the country comes from agriculture sector (BBS, 2011). During the last decade, significant changes took place in agriculture sector which include, among others, new production structure, use of high yielding varieties supported by fertilizers, pesticides, mechanized cultivation, irrigation, etc. All these changes have contributed much to the increased production of food grains. However, the land available for crop cultivation has been shrinking at round 1 percent per annum, which meant a reduction of average farm size from 0.81 ha in 1996 and further to 0.49 ha in 2005 with concomitant increase in fragmentation and subdivision of holdings. Moreover, cultivable land has gradually been degrading due to rice mono-cropping year after year (Mandal, 2007). Thus, issues relating to land tenure systems are the most aggressive in addressing the challenges of agricultural productivity in Bangladesh.

In present farming system of Bangladesh, tenancy systems occupy a considerable percentage of socioeconomic reasons which turn a farmer to be tenant (Khan, 2008). Otsuka (2007) stated that household farming or owner cultivation is the optimum form of production organization in agriculture in the context of Asian countries. In contrast, tenant cultivation is widely believed to be inefficient because of the adverse effect of tenure insecurity on long term investments as well as the disincentive effect of output sharing on work effort. Consequently, these inefficiencies affect the agricultural productivity. In view of these facts, the relative efficiency of farming under tenancy systems in Bangladesh is measured in this study. The functional analysis of the study was based on Boro rice. Therefore, the study has some specific objectives such as: (i) to document the present status of land tenure system; and (ii) to estimate the profitability of Boro rice and the contribution of key inputs to the production process of Boro rice of tenant farmers (share tenant and cash tenant). The hypotheses which guided the present study are: (i) Boro rice production is not profitable from the viewpoint of tenant farmers; and (ii) Production inputs do not have any significant impact on Boro rice production under tenancy arrangements. 


\section{RESEARCH METHODS}

Primary data for the study was collected from two adjacent villages namely, Narayanpur and Bhabokhali under Sadar Upazila of Mymensingh district. A total of 60 farmers (30 share tenant and 30 cash tenant) were selected for discussion and necessary data collection using random sampling technique. A list of various tenurial categories prevailing in the research areas was made with the help of local Sub Assistant Agricultural Officer (SAAO), village leaders and Union Parishad members of the areas. Besides, focus group discussion (FGD) of participatory rural appraisal (PRA) was conducted, being assisted by local leaders to collect data especially for assessing present status of land tenure system in the study area and also to cross check the collected data. Data were collected through direct interviews by making personal visits of the researcher to the house of selected farmers. A combination of descriptive and statistical techniques as demanded by the study was used to achieve the objectives and to get the meaningful results. Various descriptive statistical measures (i.e., sum, average, percentages, etc.) were used to examine the objective (i). Profit equation and multiple regression analysis were employed for testing the hypotheses (i) and (ii). Profit equation of the following algebraic form was used:

$\Pi=\sum_{i=1}^{n}\left(P_{Y_{i}} \cdot Y_{i}\right)-\sum_{i=1}^{n}\left(P_{X_{i}} \cdot X_{i}\right)-T F C$

Where,

$$
\begin{aligned}
& \mathrm{II} \quad=\text { Net return }(\mathrm{Tk} . / \mathrm{ha}) ; \\
& \mathrm{P}_{\mathrm{y} 1} \quad=\text { Price per unit of the } \mathrm{i} \text {-th produce }(\mathrm{Tk} . / \mathrm{kg}) ; \\
& \mathrm{Y}_{1} \quad \text { = Quantity of the } \mathrm{i}-\mathrm{th} \text { produce }(\mathrm{Kg} / \mathrm{ha}) ; \\
& \mathrm{P}_{\mathrm{x} 1} \quad=\text { Price per unit of the i-th inputs }(\mathrm{Tk} . / \mathrm{kg}) ; \\
& \mathrm{X}_{1} \quad=\text { Quantity of the } \mathrm{i}-\mathrm{th} \text { inputs }(\mathrm{Kg} / \mathrm{ha}) ; \\
& \mathrm{TFC}=\text { Total fixed costs }(\mathrm{Tk} .) ; \text { and } \\
& \mathrm{i} \quad=1,2,3, \ldots, \mathrm{n} \text { (number of items). }
\end{aligned}
$$

Cobb-Douglas revenue type production function of the following algebraic form was used in this research:

$$
Y_{i}=a X_{1_{i}}^{b_{1}} X_{2_{i}}^{b_{2}} X_{3_{i}}^{b_{3}} X_{4_{i}{ }^{b_{4}}} X_{5_{i}}^{{ }^{b_{5}}} X_{6_{i}}^{b_{6}} e^{u_{i}}
$$

This non-linear form of Cobb-Douglas model was transformed into linear form by taking natural logarithms on both sides of the equation.

$\ln Y_{i}=\ln a+b_{1} \ln X_{1_{i}}+b_{2} \ln X_{2_{i}}+b_{3} \ln _{3_{i}}+b_{4} \ln X_{4_{i}}+b_{5} \ln X_{5_{i}}+b_{6} \ln X_{6_{i}}+U_{i}$

Where,

$$
\begin{array}{ll}
Y & =\text { Gross return (Tk./ha); } \\
\ln a & =\text { Intercept or constant term; } \\
X_{1} & =\text { Human labor cost (Tk./ha); } \\
X_{2} & =\text { Power tiller cost (Tk./ha); }
\end{array}
$$




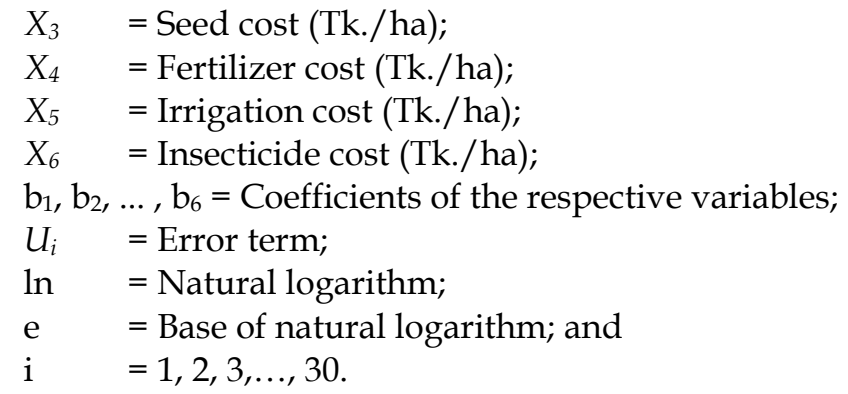

\section{RESULTS AND DISCUSSION}

\section{Present status of land tenure system}

Since the emergence, tenurial arrangements in Bangladesh are continually changing. The present land tenure system has emerged from the Land Reform Act of 1950 which abolished the Zamindar or Landlord system introduced by the British colonial rulers and ensured property rights for the farmers and dwellers. However, it had not been able to ensure equitable land distribution to people of all tiers of the society. The local elite and powerful people absorbed the benefits of land reform and became the owners of vast areas of land in the context of Bangladesh (Uddin and Haque, 2009). There are three typical types of farm holdings found in Bangladesh- farms operated by the owners, owner-cumtenant farms and tenant farms.

The land tenancy situation in rural Bangladesh shows a reasonable high incidence of owners, who cultivate their own land (69.76 percent of total farm holdings in 2005) in comparison to owner-cum-tenant (23.73 percent) and tenants (6.51 percent) as revealed by Table 1. The number of owners and tenant farms had gone up quite considerably between 1960 and 2005. On other hand, the land distribution pattern by types of tenure shows a relative decrease in owner-cum-tenant farmers (37.00 percent in 1960 and 23.73 percent in 2005).

Table 1. Percentage distribution of farm holdings by type of tenure

\begin{tabular}{l|c|c|c|c|c|c|c}
\hline \multirow{1}{*}{ Tenure class } & \multicolumn{7}{c}{ Year } \\
\cline { 2 - 8 } & 1960 & 1968 & 1974 & 1977 & 1983 & 1996 & 2005 \\
\cline { 2 - 8 } & & $\%$ of farm holdings \\
Owner operators & 61.00 & 66.00 & 67.00 & 61.00 & 62.78 & 61.66 & 69.76 \\
Owner- cum-tenant operators & 37.00 & 30.00 & 27.00 & 32.00 & 35.83 & 34.86 & 23.73 \\
Tenant operators & 2.00 & 4.00 & 6.00 & 7.00 & 1.39 & $3 . .48$ & 6.51 \\
\hline Total & 100.00 & 100.00 & 100.00 & 100.00 & 100.00 & 100.00 & 100.00 \\
\hline
\end{tabular}

Source: BBS, 2005 


\section{Tenancy arrangements in Bangladesh}

Tenant households are those households who pay rent (either in cash or in kind) to use land for cultivation or other purposes owned by another. Agriculture Census (2008) suggests that there are 8,418 thousand tenant households in the country which account for 29.36 percent of total households. Out of 29.36 percent tenant households, 1.60 percent is in urban areas and 27.76 percent are in rural areas (Table 2).

Table 2. Distribution of tenant households by urban, rural and division

\begin{tabular}{l|c|c|c|c|c|c|c}
\hline \multicolumn{1}{c|}{ Division } & $\begin{array}{c}\text { Total } \\
\text { households } \\
(\tilde{O} 000)\end{array}$ & \multicolumn{3}{c|}{$\begin{array}{c}\text { Number of tenant } \\
\text { households (Õ000) }\end{array}$} & \multicolumn{3}{c}{$\begin{array}{c}\text { Percent of tenant households } \\
(\%)\end{array}$} \\
\cline { 3 - 8 } & 1,729 & Total & Urban & Rural & Total & Urban & Rural \\
\hline Barisal & 480 & 29 & 452 & 27.76 & 1.67 & 26.09 \\
Chittagong & 4,887 & 1,337 & 111 & 1,227 & 27.36 & 2.27 & 25.09 \\
Dhaka & 9,437 & 2,386 & 133 & 2,253 & 25.28 & 1.41 & 23.87 \\
Khulna & 3,430 & 1,200 & 86 & 1,114 & 34.98 & 2.51 & 32.47 \\
Rajshahi & 7,654 & 2,639 & 95 & 2,544 & 34.48 & 1.24 & 33.24 \\
Sylhet & 1,533 & 375 & 6 & 369 & 24.46 & 0.39 & 24.07 \\
Bangladesh & 28,670 & 8,418 & 460 & 7,958 & 29.36 & 1.60 & 27.76 \\
\hline
\end{tabular}

Source: BBS, 2008

A substantial proportion of land in rural areas is owned by absentee landlords, most of whom reside in urban areas. They let their land under sharecropping arrangements (Uddin and Haque, 2009). The term sharecropping has come from the concept of share rent. Payment in kind is called 'share rent' and the system is considered as function of output by the share cropper. The farmers who operate on share arrangements are locally called Borgadar (Khan, 2008). The proportion of area under tenancy is observed to increase from about 17 percent of the operated area in 1983/84 to about 22 per cent in 1996 (BBS, 2005). This change may be due to the rapid rural-urban migration along with the increase of absentee land owners and the abandonment of some farms in favor of taking up rural non-farm occupations. There cannot be any denying of the fact that the current low productivity of agriculture is due to complex land ownership, acute sub-division and fragmentation of land holdings and absentee land ownership.

Recently, the extent of share tenancy in rural Bangladesh has been declining giving way to fixed rent tenancy or cash tenancy and medium term leasing arrangements. These institutional changes are assumed to enable tenants to derive some of the benefits of additional investment in agriculture inputs. Cash tenancy has been crop and season specific and has been confined to the cultivation of HYV rice in the Boro and Aman season. Thus, households associated with fixed rent contracts have the lowest crop diversity. Productivity is also higher on fixed-rented land than on sharecropped land (Uddin and Haque, 2009). 


\section{Land tenure arrangements in the study area}

Table 3 reveals the number and operated area of three principal categories of land tenure systems in Mymensingh district. The total number of owner farm holdings in this district was 383,900 in 2005 which comprised 4.23 percent of the country's total number, while this figure for owner-cum-tenants and tenant operators were 3.91 and 1.74 percent, respectively. The number of tenant farm holdings stood at 8,324 in 2005 in the district. The operated area under owner farm holdings was 221,964 ha which covered 4.46 percent of total operated area. On the other hand, owner-cum-tenants and tenants were observed to operate on 3.23 and 1.69 percent, respectively, of land in the district.

Table 3. Number and area of tenure categories in Mymensingh district, 2005

\begin{tabular}{lcc}
\hline \multicolumn{1}{c|}{ Items } & Bangladesh & Mymensingh \\
\hline Number of owner farm holdings & $9,065,991$ & $383,900(4.23)$ \\
Number of owner-cum-tenant farm holdings & $5,543,512$ & $216,960(3.91)$ \\
Number of tenant farm holdings & 479,584 & $8,324(1.74)$ \\
Operated area of owner farm holdings (in ha) & $4,974,632$ & $221,964(4.46)$ \\
Operated area of owner-cum-tenant farm holdings (in ha) & $3,839,721$ & $124,035(3.23)$ \\
Operated area of tenant farm holdings (in ha) & 217,129 & $3,671(1.69)$ \\
\hline
\end{tabular}

Source: BBS, 2005; Note: Figures within the parentheses indicate percentages of Bangladesh

The study villages, i.e., Narayanpur and Bhabokhali villages were found to have practiced a variety of tenurial arrangements. According to the information provided by the Sub Assistant Agricultural Officer (SAAO) and respondents in the locality, the distribution of farm operators by tenurial status presented in Table 4 was found in the research areas. Traditionally, share tenancy was the most common tenancy arrangement in the villages. However, farmers are gradually shifting from share tenancy to cash tenancy arrangement in the recent days. Mortgaging contracts arise in the face of financial crisis and this is the most common source of informal credit for the poor farmers. Some farmers mortgage-out their plots in order to efficiently cultivate other remaining crop fields. The sub-mortgage tenancy arrangements induce the mortgage tenants to further rent out the mortgaged land to another farmer. This arrangement is becoming a common phenomenon day by day. Generally, the lease contracts are adopted for fish culture in both the villages.

Because of the prevalence of a good number of share and cash tenancy arrangements in the villages, the study has attempted to assess the productivity performances of these two major tenure groups. Under share tenancy, a number of sharing agreements were practiced. The traditional 50:50 crop sharing was the common practice where land owner did not share any input cost but received half of the produce. However, this situation is changing. Some other agreements were also observed among the sampled households (share tenant) which are presented in Table 5. 
Table 4. Distribution of farms by tenurial status in the study villages

\begin{tabular}{l|c|c}
\hline \multicolumn{1}{c}{ Tenurial arrangements } & Narayanpur & Bhabokhali \\
\hline Owner cultivation & 230 & 190 \\
Owner-cum-tenant cultivation & 40 & 32 \\
\hline Tenant cultivation & & \\
$\quad$ Share tenancy & 32 & 37 \\
$\quad$ Cash tenancy & 18 & 17 \\
Lease tenancy & 8 & 7 \\
Mortgage tenancy & 8 & 11 \\
Sub-mortgage tenancy & 13 &
\end{tabular}

Source: Field survey, 2011

Table 5. Sharing agreements practiced among the sampled share tenant households in the study villages

\begin{tabular}{c|c}
\hline \multicolumn{1}{c|}{ Types of sharing agreements } & $\begin{array}{c}\text { Percentage of } \\
\text { sampled share } \\
\text { tenant households }\end{array}$ \\
\hline i. $\quad \begin{array}{l}\text { Land owner does not share any input cost and receives half of the } \\
\text { output (main product) }\end{array}$ & 17 \\
ii. $\quad \begin{array}{l}\text { Land owner shares only fertilizer and irrigation costs and receives half } \\
\text { of the output (main product) }\end{array}$ & 16 \\
iii. $\quad \begin{array}{l}\text { Land owner shares half of the input costs (fertilizer and irrigation costs) } \\
\text { and receives half of the produce (main product and by-product) }\end{array}$ & 9 \\
iv. $\begin{array}{l}\text { Land owner shares half of the input costs (seed, fertilizer and irrigation } \\
\text { costs) and receives half of the produce (main product and by-product) }\end{array}$ & 7 \\
v. $\quad \begin{array}{l}\text { Land owner shares only irrigation costs (security charges) and receives } \\
\text { half of the output (main product) with no sharing of by-product }\end{array}$ & 6 \\
vi. $\begin{array}{l}\text { Land owner shares only seed costs and receives half of the output (main } \\
\text { product) with no sharing of by-product }\end{array}$ & 21 \\
vii. $\begin{array}{l}\text { Land owner shares no input cost and receives a fixed amount of output } \\
\text { per unit area of land, i.e., } 1 \text { maund/kantha for paddy and half of the } \\
\text { paddy straw }\end{array}$ & 12 \\
viii. Land owner shares no input cost and receives one third of the produce \\
(main product and by-product)
\end{tabular}

Source: Field survey, 2011

\section{Profitability of Boro rice production}

For estimating net return per hectare of Boro rice production for both share tenants and cash tenants, at first the costs of production and then the value of output (gross return) was calculated to obtain the value of net return by deducting the costs from the gross return. The results of the estimation are presented in Table 6 for both share and cash tenant farmers. 
Table 6. Per hectare costs and return of Boro rice production of tenants farmers

\begin{tabular}{|c|c|c|c|c|c|c|}
\hline \multirow[t]{2}{*}{ Items } & \multicolumn{3}{|c|}{ Share tenant } & \multicolumn{3}{|c|}{ Cash tenant } \\
\hline & \begin{tabular}{|c|}
$\begin{array}{c}\text { Quantity } \\
\text { (per } \\
\text { hectare) }\end{array}$ \\
\end{tabular} & $\begin{array}{c}\text { Price } \\
\text { (Tk./unit) }\end{array}$ & \begin{tabular}{|c|} 
Total \\
value $(\mathrm{Tk})$.
\end{tabular} & $\begin{array}{l}\text { Quantity } \\
\text { (per } \\
\text { hectare) }\end{array}$ & $\begin{array}{c}\text { Price } \\
\text { (Tk./unit) }\end{array}$ & $\begin{array}{c}\text { Total } \\
\text { value (Tk.) }\end{array}$ \\
\hline \multicolumn{7}{|l|}{ A. Total Return } \\
\hline Paddy (kg) & $4,662.12$ & 17.83 & $83,126.05$ & $4,878.67$ & 17.83 & $87,016.17$ \\
\hline Paddy straw (kg) & $1,783.47$ & 5.45 & $9,672.27$ & $2,064.67$ & 5.45 & $11,295.50$ \\
\hline Total & - & - & $92,798.32$ & - & - & $98,311.67$ \\
\hline B. Total Costs & - & - & & - & - & \\
\hline Seedlings ((kg) & 39.15 & 37.67 & $1,466.71$ & 38.47 & 37.83 & $1,451.37$ \\
\hline Power tiller & - & - & $4,686.67$ & - & - & $4,820.67$ \\
\hline \multicolumn{7}{|l|}{ Human labor (man-day) } \\
\hline Land preparation & 30.85 & 200.00 & $6,170.00$ & 31.30 & 200.00 & $6,260.83$ \\
\hline Transplanting & 32.19 & 220.00 & $7,080.96$ & 33.17 & 220.00 & $7,295.60$ \\
\hline Weeding & 16.68 & 200.00 & $3,335.79$ & 17.35 & 200.00 & $3,469.44$ \\
\hline Fertilizer application & 11.52 & 200.00 & 2,303.99 & 11.00 & 200.00 & $2,366.30$ \\
\hline Insecticide application & 8.82 & 200.00 & $1,763.92$ & 8.93 & 200.00 & $1,786.62$ \\
\hline Harvesting & 30.68 & 250.00 & $7,668.89$ & 31.22 & 250.00 & $7,804.21$ \\
\hline Threshing & 20.77 & 250.00 & $5,191.36$ & 20.99 & 250.00 & $5,246.71$ \\
\hline Cleaning and drying & 18.93 & 200.00 & $3,786.31$ & 19.01 & 200.00 & $3,801.22$ \\
\hline \multicolumn{7}{|l|}{ Inorganic fertilizer (kg) } \\
\hline Urea & 255.21 & 12.00 & $3,062.57$ & 268.98 & 12.00 & $3,227.72$ \\
\hline TSP & 123.91 & 32.00 & $3,976.19$ & 127.99 & 32.00 & $4,123.44$ \\
\hline $\mathrm{MP}$ & 61.76 & 25.00 & $1,543.99$ & 69.79 & 25.00 & $1,780.30$ \\
\hline $\mathrm{ZnSO}_{4}$ & 58.15 & 8.00 & 465.19 & 57.51 & 8.00 & 460.05 \\
\hline \multicolumn{7}{|l|}{ Organic fertilizer (kg) } \\
\hline Cowdung & 750.00 & 1.25 & 937.50 & 760.00 & 1.25 & 950.00 \\
\hline Irrigation water & - & - & $7,144.00$ & - & - & $7,030.00$ \\
\hline Insecticide & - & - & 439.12 & - & - & 453.91 \\
\hline Interest on operating cost & - & - & $1,220.46$ & - & - & $1,246.57$ \\
\hline Land rental value & - & - & $10,820.00$ & - & - & $11,400.00$ \\
\hline $\begin{array}{l}\text { Depreciation of farm } \\
\text { implements }\end{array}$ & - & - & 482.52 & - & - & 520.81 \\
\hline Total & - & - & $73,546.14$ & - & - & $75,495.77$ \\
\hline C. Net Return (A-B) & - & - & $19,252.18$ & - & - & $22,815.89$ \\
\hline
\end{tabular}

Source: Field survey, 2011

\section{Estimation of costs}

Costs are the expenses incurred in organizing and carrying out the production process (Doll and Orazem, 1984). These include variable costs and fixed costs of production. The variable costs of Boro rice from the viewpoint of tenant farmers include the cost of human labor (both home supplied and purchased), power tiller for land preparation, seed, 
fertilizer, manure, irrigation and insecticide. Here, the fixed costs include interest on operating cost, land rental value and depreciation of farm implements. Farmers used both home supplied and purchased inputs. The costs of the purchased inputs were estimated on the basis of the actual payments made by the farmers and for home supplied inputs, opportunity cost principle was applied to determine their value.

\section{Estimation of gross return}

Per hectare gross return from Boro rice production includes the monetary value of physical produces obtained from the production process. Here, the output includes the physical quantities of main product (paddy) and by-product (paddy straw). Total return was estimated by multiplying the total physical quantities of both main product and byproduct by their respective market prices.

\section{Results of profitability analysis:}

The results presented in Table 6 clearly indicate that Boro rice cultivation was profitable from the viewpoint of both tenant operators. In fact, per hectare net return of share tenant was Tk. 19,252.18 and that of cash tenant was Tk. 22,815.89 which indicates that cash tenants earned more profit (Tk. 3,563.72) than the share tenants. The difference in profit earned between the cash tenant and share tenant operators was statistically significant at 10 percent probability level as indicated by the $t$-value in Table 7 .

Table 7. Net return of tenant farmers

\begin{tabular}{|c|c|c|}
\hline Particulars & Share tenant & Cash tenant \\
\hline Net return (Tk.) & $19,252.18$ & $22,815.89$ \\
\hline $\begin{array}{l}\text { Difference in net return } \\
\text { (Cash tenant over share tenant) }\end{array}$ & \multicolumn{2}{|c|}{$\begin{array}{l}3,563.72^{*} \\
(2.87)\end{array}$} \\
\hline
\end{tabular}

Source: Author's estimation based on field survey, 2011, Note: Figure in the parenthesis indicates t-value, * Significant at 10 percent level

Fifty : fifty crop sharing which was the most common sharing arrangement in the study area may give a reasonable explanation for the difference in profit earned between the cash tenant and share tenant operators. In this sharing arrangement, the share tenants do not get any return for their labour and management inputs. This acts as a disincentive among the share tenant operators which ultimately affects the intensification of production as well as the returns from production as compared to cash tenants who give a fixed amount to the landowner on receiving a share of input costs by the landowners. This is the fact which can be concluded through this research in the study area.

Although there was significant difference in the profit earned between cash tenants and share tenants, the above finding supports the rejection of hypothesis (i). Eventually, it can be concluded that Boro rice production was profitable from the viewpoint of both tenant operators. 


\section{Contribution of production inputs on Boro rice production under tenancy arrangements}

Cobb-Douglas revenue type production function of the following form was chosen for estimating the impact of key variables to the production process of Boro rice under tenancy (share and cash tenancy) arrangements. Under both arrangements, six variables were identified as key contributor to the production process. These are human labor cost $\left(X_{1}\right)$, power tiller cost $\left(X_{2}\right)$, seed cost $\left(X_{3}\right)$, fertilizer cost $\left(X_{4}\right)$, irrigation cost $\left(X_{5}\right)$ and insecticide cost $\left(\mathrm{X}_{6}\right)$. There are many other variables (e.g., climatic conditions, soil fertility, time of sowing, management, etc.) which affect the production process directly or indirectly. However, these were not considered in this study.

The individual contribution of key inputs to the production process of Boro rice can be seen from the estimates of their respective coefficients. Most of the inputs included in the models were found to have significant impact on the production process of Boro rice under both tenancy arrangements. Power tiller had insignificant impact on Boro rice production under share tenancy arrangement but a significant and negative impact under cash tenancy arrangement. This negativity impact may be due to the fact that cash tenants in the study area were spending more than required amount for preparing their Boro rice field. Insecticides were found to have a negative and insignificant impact. Excessive usage of insecticides made by the tenant operators in the study area yielded negative and insignificant value of the coefficient. Cobb-Douglas revenue type production function fitted well for Boro rice production under tenancy arrangements as indicated by the $\mathrm{R}^{2}$ values ( 0.702 for share tenants and 0.707 for cash tenants) and F-values (9.030 for share tenants and 9.245 for cash tenants). The F-values were highly significant at 1 percent probability level (Table 8).

Table 8. Estimated values of regression coefficients and related statistics of Cobb-Douglas revenue type production function for tenant farmers

\begin{tabular}{|c|c|c|c|c|c|c|}
\hline \multirow[t]{2}{*}{ Regressors } & \multicolumn{3}{|c|}{ Share tenant } & \multicolumn{3}{|c|}{ Cash tenant } \\
\hline & $\begin{array}{l}\text { Estimated } \\
\text { coefficient }\end{array}$ & $\begin{array}{c}\begin{array}{c}\text { Standard } \\
\text { error }\end{array} \\
\end{array}$ & t-value & $\begin{array}{l}\text { Estimated } \\
\text { coefficient }\end{array}$ & $\begin{array}{c}\begin{array}{c}\text { Standard } \\
\text { error }\end{array} \\
\end{array}$ & t-value \\
\hline Constant & 6.394 & 0.858 & 7.452 & 5.478 & 0.92 & 5.954 \\
\hline Human labor cost $\left(\mathrm{X}_{1}\right)$ & $0.524^{* *}$ & 0.214 & 2.449 & $0.613^{\text {** }}$ & 0.244 & 2.512 \\
\hline Power tiller cost $\left(X_{2}\right)$ & 0.137 & 0.092 & 1.489 & $-0.120^{*+* t+}$ & 0.056 & -2.14 \\
\hline Seed $\operatorname{cost}\left(X_{3}\right)$ & $0.348^{\text {*t+k}}$ & 0.11 & 3.164 & $0.373^{\text {** }}$ & 0.153 & 2.438 \\
\hline Fertilizer cost $\left(X_{4}\right)$ & $0.243^{* *}$ & 0.102 & 2.382 & $0.336^{* * *}$ & 0.109 & 3.083 \\
\hline Irrigation cost $\left(X_{5}\right)$ & $0.443^{*}$ & 0.173 & 2.561 & $0.501^{*}$ & 0.185 & 2.708 \\
\hline Insecticide cost $\left(X_{6}\right)$ & -0.114 & 0.076 & -1.5 & -0.091 & 0.069 & -1.32 \\
\hline $\mathrm{R}^{2}$ & & 0.702 & & & 0.707 & \\
\hline Adjusted $\bar{R}^{2}$ & & 0.624 & & & 0.630 & \\
\hline F-value & & $9.030^{* \star *}$ & & & $9.245^{\text {***}}$ & \\
\hline Returns to scale $\left(\sum \mathrm{b}_{\mathrm{i}}\right)$ & & 1.581 & & & 1.612 & \\
\hline
\end{tabular}

Source: Author's estimation based on field survey, 2011

Note: *** Significant at 1 percent level, ** Significant at 5 percent level, * Significant at 10 percent level 
The values of returns to scale were 1.581 and 1.612 for share tenant and cash tenant farmers. That is, the production function exhibits increasing returns to scale and both category of tenant farmers were operating in the first stage of production. The tenant farmers were receiving relatively lower yield per hectare in the study area. Thus, they have a greater scope for increasing their Boro rice production by applying more inputs.

Therefore, based on the above findings it can be concluded that variables (production inputs) included in the model had significant impact on the production process of Boro rice under tenancy arrangements. They were responsible either individually or jointly for variation in gross return which rejects hypothesis (ii).

\section{CONCLUSION}

The study highlighted the fact that there were productivity differences between the share tenants and cash tenants due to the differences in resource endowments. Cash tenants earned more profit than share tenants from Boro rice production. Majority of the share tenants were receiving only half of the produce after investing in all the costs of production along with the share of their labor and management inputs although the picture was different for some share tenants who gave one third of the produce to landowner as rent. This somewhat acts as a disincentive towards intensive cultivation of land. Therefore, the existing sharing system between landowner and tenants should be uniform and modified throughout the study areas. The Tebhaga system should be implemented in all the areas of Bangladesh.

\section{REFERENCES}

Awal, M. A., Saha, S. R., Khaled, M. M. and Khan, M. A. 2007. An economic analysis of sweet potato cultivation in some selected char areas of Bangladesh. J. Bangladesh University, 5(1): 159-167.

BBS. 2005. Agriculture Census Survey 2005, Bangladesh Bureau of Statistics, Planning Division, Ministry of Planning, Government of the People's Republic of Bangladesh, Dhaka.

BBS. 2008. Agriculture Census 2008, Bangladesh Bureau of Statistics, Planning Division, Ministry of Planning, Government of the People's Republic of Bangladesh, Dhaka.

BBS. 2011. Statistical Yearbook of Bangladesh, Bangladesh Bureau of Statistics, Ministry of Planning, Government of the People's Republic of Bangladesh, Dhaka.

Bishop, C. C. and Toussaint, W. D. 1958. Introduction to agricultural economic analysis. John Willey and Sons, New York.

Bruce, J. 1993. Do indigenous tenure systems constraint agricultural development? In: Bassett, T. and Crummy, D. (eds). Land in African agrarian systems, Madison, WI: University of Wisconsin Press. pp. 35-56. 
Doll, J.P. and Orazem, F. (1984). Production economics: Theory with applications. John Wiley and Sons, Inc.

FAO. 1993. Food and Agriculture Organization of the United Nations. Land tenure and rural development. Chapter 3. What is land tenure?

URL: http://www.fao.org/docrep/005/y4307e/y4307e05.htm (Accessed on 28/10/2011)

GOB. 2008. Moving ahead, National strategy for accelerating poverty reduction (2009-10), General Economic Division, Planning Commission, Government of the People's Republic of Bangladesh.

Khan, T. 2008. An economic analysis of the impact of land tenure system on Boro paddy production in a selected area of Mymensingh district. An unpublished M.S. Thesis, Department of Agricultural Economics, Bangladesh Agricultural University, Mymensingh.

Mandal, M. A. S. 2007. Challenges of agricultural research for poverty reduction in Bangladesh. A paper presented at the seminar on poverty alleviation through agricultural research in Bangladesh: Challenges for the 21 ${ }^{\text {st }}$ Century, Bangladesh Agricultural University, Mymensingh, Bangladesh, 16 June 2007.

Otsuka, K. 2007. Efficiency and equity effects of land markets. In: Evenson, R.E., Pingali, P., editors. Handbook of agricultural economics. Volume 3. Amsterdam (Netherlands): Elsevier.

Uddin, Akand, M. F. and Haque, J. T. 2009. Agrarian transition and livelihoods of the rural poor: The agricultural land market. Publication of Unnayan-Onneshan, The Innovators. 